\title{
Artepillin C Reduces Allergic Airway Inflammation by Induction of Monocytic Myeloid-Derived Suppressor Cells
}

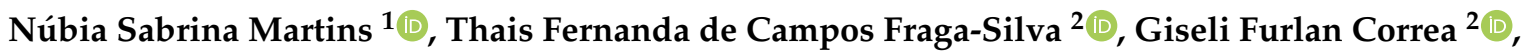 \\ Mèdéton Mahoussi Michaël Boko ${ }^{1}$, Leandra Naira Zambelli Ramalho ${ }^{3}$, Débora Munhoz Rodrigues ${ }^{4}$, \\ Juliana Issa Hori ${ }^{5} \mathbb{C}^{-}$, Diego Luis Costa ${ }^{1,2} \mathbb{C}$, Jairo Kenupp Bastos ${ }^{4}$ and Vânia Luiza Deperon Bonato ${ }^{1,2, *(\mathbb{C})}$
}

Citation: Martins, N.S.; de Campos Fraga-Silva, T.F.; Correa, G.F.; Boko, M.M.M.; Ramalho, L.N.Z.; Rodrigues, D.M.; Hori, J.I.; Costa, D.L.; Bastos, J.K.; Bonato, V.L.D. Artepillin C Reduces Allergic Airway Inflammation by Induction of Monocytic Myeloid-Derived Suppressor Cells. Pharmaceutics 2021, 13, 1763. https://doi.org/10.3390/ pharmaceutics 13111763

Academic Editor: Ariane Leite Rozza

Received: 20 August 2021

Accepted: 30 September 2021

Published: 22 October 2021

Publisher's Note: MDPI stays neutral with regard to jurisdictional claims in published maps and institutional affiliations.

Copyright: (c) 2021 by the authors. Licensee MDPI, Basel, Switzerland. This article is an open access article distributed under the terms and conditions of the Creative Commons Attribution (CC BY) license (https:// creativecommons.org/licenses/by/ $4.0 /)$
1 Basic and Applied Immunology Program, Ribeirao Preto Medical School, University of Sao Paulo, Ribeirao Preto 14049-900, Sao Paulo, Brazil; nsmartins@usp.br (N.S.M.); bokmich@usp.br (M.M.M.B.); dlcosta@usp.br (D.L.C.)

2 Department of Biochemistry and Immunology, Ribeirao Preto Medical School, University of Sao Paulo, Ribeirao Preto 14049-900, Sao Paulo, Brazil; thaisfragasilva@usp.br (T.F.d.C.F.-S.); giselifurlan@usp.br (G.F.C.)

3 Department of Pathology and Legal Medicine, Ribeirao Preto Medical School, University of Sao Paulo, Ribeirao Preto 14049-900, Sao Paulo, Brazil; 1ramalho@fmrp.usp.br

4 Department of Pharmaceutical Sciences, School of Pharmaceutical Sciences, University of Sao Paulo, Ribeirao Preto 14049-900,Sao Paulo, Brazil; debora_munhoz@yahoo.com.br (D.M.R.); jkbastos@fcfrp.usp.br (J.K.B.)

5 Apis Flora Industrial and Comercial Ltda, Ribeirao Preto 14020-670, Sao Paulo, Brazil; julianabio2000@gmail.com

* Correspondence: vlbonato@fmrp.usp.br

Abstract: Propolis is a natural product produced by bees that is primarily used in complementary and alternative medicine and has anti-inflammatory, antibacterial, antiviral, and antitumoral biological properties. Some studies have reported the beneficial effects of propolis in models of allergic asthma. In a previous study, our group showed that green propolis treatment reduced airway inflammation and mucus secretion in an ovalbumin (OVA)-induced asthma model and resulted in increased regulatory T cells (Treg) and polymorphonuclear myeloid-derived suppressor cells (PMN-MDSC) frequencies in the lungs, two leukocyte populations that have immunosuppressive functions. In this study, we evaluated the anti-inflammatory effects of artepillin C (ArtC), the major compound of green propolis, in the context of allergic airway inflammation. Our results show that ArtC induces in vitro differentiation of Treg cells and monocytic MDSC (M-MDSC). Furthermore, in an OVA-induced asthma model, ArtC treatment reduced pulmonary inflammation, eosinophil influx to the airways, mucus and IL-5 secretion along with increased frequency of M-MDSC, but not Treg cells, in the lungs. Using an adoptive transfer model, we confirmed that the effect of ArtC in the reduction in airway inflammation was dependent on M-MDSC. Altogether, our data show that ArtC exhibits an anti-inflammatory effect and might be an adjuvant therapy for allergic asthma.

Keywords: propolis; artepillin C; allergic asthma; M-MDSC; therapies

\section{Introduction}

Propolis is a resin made by working Apis mellifera Linnaeus, 1758 bees from exudates and new buds of different plant species, which is traditionally used in alternative and complementary medicine. The Brazilian green propolis has the shrub Baccharis dracunculifolia DC as its primary botanical source and is rich in prenylated derivative compounds. It has gained notoriety for displaying anti-inflammatory, immunomodulatory, antitumoral, antibacterial, and antiviral proprieties [1-4]. Experimental evidence of anti-inflammatory actions of propolis was demonstrated in several murine models of inflammatory diseases. Those actions include the reduction in neutrophils and the levels of pro-inflammatory cytokines IL-6 and TNF- $\alpha$ in the bronchoalveolar lavage fluid (BALF) during LPS-induced pulmonary inflammation [5]; reduction in neutrophil infiltration and serum levels of IL-6, 
IL-1 $\beta$ and TNF- $\alpha$ in experimental pancreatitis [6], and decreased production of reactive oxygen species (ROS) in ethanol-induced gastric ulcers [7]. In the type 2 inflammation induced by inhaled allergen, the treatment with propolis during the sensitization phase resulted in reduction in allergen-specific IgE, airway inflammation, and hyper-reactivity [8] and in a decreased number of inflammatory cells in the BALF [9]. Our research group characterized the anti-inflammatory action of green propolis in sensitized and challenged mice and showed a reduction in pulmonary inflammation and mucus secretion [10], suggesting a protective effect for propolis treatment in asthma.

Asthma is a chronic inflammatory lung disease that affects 339 million people worldwide [11]. Bronchial hyper-reactivity, mucus overproduction and airway remodeling induce symptoms such as shortness of breath, cough, and wheezing [12,13]. Although there are different disease phenotypes, the hallmark of allergic asthma is a type 2 immune response, characterized by IL-4, IL-5, and IL-13 secretion by T helper 2 (Th2) lymphocytes, IgE secretion, recruitment and activation of eosinophils, mast cells, dendritic cells and epithelial cells [12]. Currently, therapy with corticoids configures the most efficient treatment to control the disease symptoms but it does not cure asthma. Moreover, the recurrent use of corticoids favors the development of infections and impairs childhood development [12,14]. Therefore, there is an urgent need for new therapies for allergic asthma, both to control disease symptoms as well as to improve the life quality of asthmatic patients.

Although propolis treatment represents a promising strategy for immunotherapy, it is also challenging considering the isolation of the compounds that display the antiinflammatory effects. Artepillin C (ArtC) (3,5-Diprenyl-4-hydroxicinnamic) is a prenylated phenolic compound derived from cinnamic acid and is one of the main components in green propolis [15]. Some in vitro studies demonstrated that ArtC inhibits ROS production, cytokine secretion and blocks NF- $\kappa B$ expression in IFN- $\gamma$-stimulated RAW264.7 macrophage cell lineage [16]. Additionally, ArtC exhibits an anti-inflammatory role in an experimental model of peritonitis, in which it induces reduction in leukocyte and $\mathrm{PGE}_{2}$ levels in peritoneal exudate [17].

In this study, we aimed to evaluate the anti-inflammatory activity of ArtC in allergic airway inflammation. We hypothesized that ArtC induces regulatory $\mathrm{CD}^{+} \mathrm{T}(\mathrm{Treg})$ cells and myeloid-derived suppressor cells (MDSC), which negatively regulates allergic pulmonary inflammation. Treg cells are involved in the regulation of immune response by suppressing the function of effector T cells (Th1, Th2, Th17, and CD8 ${ }^{+} \mathrm{T}$ cells) [18]. MDSC comprises a heterogeneous cell population derived from bone marrow that expands in situations of physiological stress, such as chronic inflammation and tumors, and also display immunosuppressive actions [19-21]. There are two subsets of MDSC: the granulocytic (PMN-MDSC) and the monocytic (M-MDSC), which are classified according to their origin, either from granulocytic or monocytic myeloid cells lineages [22,23].

We showed that ArtC treatment reduced eosinophilic lung inflammation in an ovalbumin (OVA)-induced allergic asthma model and induced M-MDSC differentiation in vivo and in vitro. Finally, we performed ArtC treated-M-MDSC transfer to animals sensitized and challenged with the allergen and confirmed that the decrease in eosinophilic lung inflammation was dependent on ArtC.

\section{Materials and Methods}

\subsection{Artepillin C (ArtC) Isolation}

ArtC was isolated from the crude extract of green propolis provided by Apis Flora Company (Ribeirao Preto, SP, Brazil). First, the green propolis was frozen, pulverized in a blender, and extracted with hydroalcoholic solution (9:1) to furnish the crude hydroalcoholic extract. It was fractioned using a silica gel open chromatographic column with a gradient elution consisting of hexane-ethyl acetate 95:05 to 90:10 v/v furnishing approximately 100 fractions. Each fraction was analyzed by TLC (thin-layer chromatography), concentrated under vacuum, and combined according to its chromatographic similarities. The fractions were analyzed by HPLC-DAD (high-performance liquid chromatography 
with a diode-array detector) using authentic ArtC standard. Then, the fractions rich in ArtC were purified by preparative HPLC-UV at $275 \mathrm{~nm}$ furnishing $68 \mathrm{mg}$ of pure ArtC with relative purity of $95 \%$. The elution program consisted of $7 \mathrm{~min}$ gradient with $80 \%$ B (methanol) and 20\% A (99\% water, 1\% formic acid), 12 min with $85 \%$ B, 20 min with $90 \%$ B 22 min with $95 \%$ B, and a flow rate of $8.0 \mathrm{~mL} / \mathrm{min}$, and detection at $275 \mathrm{~nm}$, using a reverse-phase column (Shimadzu Shim-pack prep.-ODS $15 \mu \mathrm{m}, 20 \times 250 \mathrm{~mm}$ ) [24]. ArtC chemical structure was confirmed by spectroscopic (1H NMR), and spectrometric (High-resolution ESI-MS) analyses. ArtC was solubilized in DMSO and maintained at $-80{ }^{\circ} \mathrm{C}$ until the moment of use. For in vivo experiments, ArtC-DMSO was diluted in phosphate buffered sSaline (PBS) with a final concentration of $0.05 \%$ of DMSO. For in vitro experiments, ArtC-DMSO was diluted in RPMI 1640 (Sigma-Aldrich, St. Louis, MO, USA) with a final concentration $\leq 1.8 \%$ DMSO.

\subsection{Animals}

Female C57BL/ 6 mice (6-8 weeks old) were obtained from the breeding facility of Ribeirao Preto Medical School, University of São Paulo (Ribeirao Preto, SP, Brazil). All animals were maintained in sterile environmental conditions in a ventilated rack (Alesco, Monte Mor, SP, Brazil) and received sterile food and water. Body weight was measured weekly. All experiments were performed according to the local Ethics Committee on Animal Experimentation (Protocol Number 216/2019).

\subsection{OVA-Induced Asthma Model}

Mice were sensitized three times with $10 \mu \mathrm{g}$ of ovalbumin (OVA) Grade-VI emulsified in $2 \mathrm{mg}$ of aluminum hydroxide (alum) (all from Sigma-Aldrich, St. Louis, MO, USA) by intraperitoneal route with seven-day intervals. Mice were challenged three consecutive days with $30 \mu \mathrm{g}$ of OVA Grade V (Sigma-Aldrich, St. Louis, MO, USA) by intranasal route seven days after the third sensitization. For challenge, mice were anesthetized with ketamine (100 mg/kg, Sespo Industry and Commerce, Paulínia, SP, Brazil) and xylazine $(10 \mathrm{mg} / \mathrm{kg}$, Vetecia Laboratory of Veterinary Products, Jacareí, SP, Brazil).

\subsection{Treatment}

Mice were treated with seven doses of vehicle (PBS, $0.05 \%$ DMSO) or ArtC ( $80 \mu \mathrm{g}$, $0.05 \% \mathrm{DMSO}$ ) by intranasal route $24 \mathrm{~h}$ after the third allergen challenge in alternate days. After the end of treatment, the mice were challenged with the allergen three more times. For challenge, mice were anesthetized with ketamine $(100 \mathrm{mg} / \mathrm{kg}$, Sespo Industry and Commerce, Paulínia, SP, Brazil) and xylazine $(10 \mathrm{mg} / \mathrm{kg}$, Vetecia Laboratory of Veterinary Products, Jacareí, SP, Brazil).

\subsection{Bronchoalveolar Lavage}

To assess bronchoalveolar lavage fluid (BALF), animals were anesthetized with ketamine $(100 \mathrm{mg} / \mathrm{kg}$, Sespo Industry and Commerce, Paulínia, SP, Brazil) and xylazine $(10 \mathrm{mg} / \mathrm{kg}$, Vetecia Laboratory of Veterinary Products, Jacareí, SP, Brazil). Then, the trachea was exposed and cannulated with Angiocath with subsequent injection of $4 \mathrm{~mL}$ of PBS. Next, samples were centrifuged at $450 \times g$ for $5 \mathrm{~min}$. The supernatant was stored at -20 ${ }^{\circ} \mathrm{C}$ for cytokine measurement. Cells were resuspended in $500 \mu \mathrm{L}$ of RPMI 1640 (SigmaAldrich, St. Louis, MO, USA), centrifuged at cytocentrifuge (Thermo Fisher Scientific, Waltham, MA, EUA) at $18 \times g$ for $3 \mathrm{~min}$, and stained with rapid panoptic (Labor Clin, Sao José do Rio Preto, SP, Brazil) for differential cell count.

\subsection{Lung Homogenate}

After collection of BALF, animals were perfused with $5 \mathrm{~mL}$ of PBS. Left lung lobules were mechanically macerated in microtubes containing protease inhibitor (Sigma-Aldrich, St. Louis, MO, USA) and centrifuged at $3220 \times g$ for $15 \mathrm{~min}$. The supernatant was collected and maintained at $-20^{\circ} \mathrm{C}$ for cytokine measurement. 


\subsection{Histopathology}

The histopathological analysis was performed as previously described [25]. Briefly, right lung lobules were stained with hematoxylin and eosin (H\&E) to evaluate the inflammatory infiltrate and periodic acid-Schiff (PAS) to evaluate mucus production. Histological images were performed using the objective lens of $20 \times($ magnification $200 \times$ ). Pulmonary inflammation score was determined following the criteria: 0 -without inflammation; 1 -mild inflammation, and 2-moderate to severe inflammation. Mucus score was determined following the criteria: 0 - without mucus production, and $1-$ mild mucus production.

\subsection{MDSC Differentiation}

Bone marrow-derived MDSC were generated according to Solito and colleagues [26] from female C57BL/6 mice. Briefly, cells were stimulated with recombinant IL-6 (40 ng/mL, BD Pharmingen, San Diego, CA, USA) and GM-CSF (40 ng/mL, BD Pharmingen, San Diego, CA, USA) in the presence or absence of $\operatorname{ArtC}(0.01,0.1,5,10,20,50$, or $100 \mu \mathrm{M})$. Cells were cultured for $96 \mathrm{~h}$, at $37^{\circ} \mathrm{C}$ and $5 \% \mathrm{CO}_{2}$.

\subsection{Treg Cell Differentiation}

Naive T cells $\left(\mathrm{CD}^{+} \mathrm{CD}^{2} \mathrm{~L}^{+}\right)$from spleen and lymph nodes of female C57BL/ 6 mice, purified using magnetic beads (Mylteni Biotec, Bergisch Gladbach, NRW, Germany), were distributed in plates previously coated overnight with monoclonal antibody anti-CD3 $(5 \mu \mathrm{g} / \mathrm{mL}$, BD Pharmingen, San Diego, CA, USA) in the presence of anti-CD28 $(1 \mu \mathrm{g} / \mathrm{mL})$, rTGF- $\beta$ (3 ng/mL, BD Pharmingen, San Diego, CA, USA) and rIL-2 (10 ng/mL, BD Pharmingen, San Diego, CA, USA), treated or not with ArtC $(0.01,0.1,5,10,20,50$ or $100 \mu \mathrm{M})$. For Treg cell differentiation, cells were cultured for $96 \mathrm{~h}$, at $37^{\circ} \mathrm{C}$ and $5 \% \mathrm{CO}_{2}$.

\subsection{Flow Cytometry}

Lung cells were isolated by proper right lung lobules digestion using collagenase (2.2 mg/mL) (Sigma-Aldrich, St. Louis, MO, USA) and DNAse $(0.055 \mathrm{mg} / \mathrm{mL})$ (Roche, Basel, Switzerland). Characterization of MDSC and Treg cells was performed by flow cytometry according to antibodies fabricant instructions (BD Pharmingen, San Diego, CA, USA). Samples were stained with FVS780 viability stain, CD45, CD11b, Ly6C, and Ly6G to characterize MDSC and CD45, CD4, and Foxp3 to characterize Treg cells (Table 1). Samples were fixed using PBS containing 1\% paraformaldehyde (Labsynth, Diadema, SP, Brazil). The samples were acquired in FACS Melody (BD Biosciences, San Jose, CA). On average, two hundred and fifty thousand events per sample were collected within the gate of viable cells $\left(\mathrm{FVS}_{780^{-}}\right.$). Analyses were performed in FlowJo software (Becton Dickinson and Company, Franklin Lakes, NJ, USA).

Table 1. Monoclonal antibodies used in flow cytometry assays.

\begin{tabular}{cccc}
\hline Cell Type & Antibody & Fluorochrome & Clone \\
\hline \multirow{3}{*}{ In vitro MDSC } & CD11b & PE-Cy7 & M1/70 \\
& Ly6C & PerCP Cy5.5 & AL-21 \\
& Ly6G & APC & 1A8 \\
\hline \multirow{2}{*}{ In vitro Treg cell } & CD4 & BB700 & RM4-5 \\
& Foxp3 & PE & MF23 \\
\hline \multirow{3}{*}{ In vivo MDSC } & CD45 & PE-Cy7 & $30-F 11$ \\
& CD11b & FITC & M1/70 \\
& Ly6C & PerCP Cy5.5 & AL-21 \\
& Ly6G & APC & 1 A8 \\
\hline \multirow{2}{*}{ In vivo Treg cell } & CD45 & PE-Cy7 & 30-F11 \\
& CD4 & BB700 & RM4-5 \\
& Foxp3 & PE & MF23 \\
\hline
\end{tabular}




\subsection{M-MDSC Adoptive Transfer}

For adoptive transfer, MDSC were generated in the presence or absence of ArtC $(10 \mu \mathrm{M})$. Subsequently, M-MDSC (Ly6G $\mathrm{G}^{-} \mathrm{Ly}_{6 \mathrm{C}}{ }^{+}$) were purified using FACS Melody sorting (BD Biosciences, San Jose, CA, USA), and $1 \times 10^{5}$ cells were transferred by intrapharyngeal route to OVA sensitized-mice during the second allergen challenge. Twenty-four hours after the third challenge, animals were euthanized to evaluate lung inflammation.

\subsection{Cytokines}

IL-4, IL-5, IL-10, and IL-13 levels were determined in BALF and lung homogenates using ELISA kits following the manufacturer's instructions (R\&D Systems, Minneapolis, MN, USA). The limit of detection was $31.2 \mathrm{pg} / \mathrm{mL}$.

\subsection{Statistical Analysis}

Data were analyzed using GraphPad Prism Version 8.1 (GraphPad Software, Inc., San Diego, CA, USA). Two-group comparisons were analyzed by non-paired t-test, and three or more groups' comparisons were calculated by ANOVA one-way followed by Tukey's test. Correlation analyses were performed following Pearson's correlation coefficient. The histological score was calculated by the Chi-square test. Data were shown as the mean \pm standard deviation (SD), and the results were considered significant with a $p$-value less than 0.05 .

\section{Results}

\subsection{ArtC Isolation}

The chromatographic processes used to obtain pure ArtC were previously reported by Rodrigues and colleagues [24] and yielded approximately $68 \mathrm{mg}$ of purified compound, which was used for running the biological assays. ArtC chemical structure was confirmed by ${ }^{1} \mathrm{H} \mathrm{NMR}\left(\mathrm{CDCl}_{3}, 300 \mathrm{MHz}\right) \delta \mathrm{H}: 7.72(\mathrm{~d}, 1 \mathrm{H}, \mathrm{J} 15.9 \mathrm{~Hz}, \mathrm{H} 7), 7.22(\mathrm{~s}, 2 \mathrm{H}, \mathrm{H} 6$ and H2), 6.31 (d, 1H, J $15.9 \mathrm{~Hz}, \mathrm{H} 8), 5.33$ (t, 2H, J 7.2 Hz H2', and H2' $), 3.37$ (d, 4H, J $15.9 \mathrm{~Hz}, \mathrm{H} 1^{\prime}$, and $\left.\mathrm{H} 1^{\prime \prime}\right)$, and $1.80\left(\mathrm{~d}, 12 \mathrm{H}, \mathrm{H}^{\prime}, \mathrm{H}^{\prime \prime}, \mathrm{H}^{\prime}\right.$, and $\left.\mathrm{H}^{\prime \prime}\right)$. For $\mathrm{C}_{19} \mathrm{H}_{24} \mathrm{O}_{3}[\mathrm{M}+\mathrm{H}]^{+}: 301.1759$ (Figure 1a); found $\mathrm{C}_{19} \mathrm{H}_{24} \mathrm{O}_{3}[\mathrm{M}+\mathrm{H}]^{+}: 301.1790$ (Figure 1b).

a)

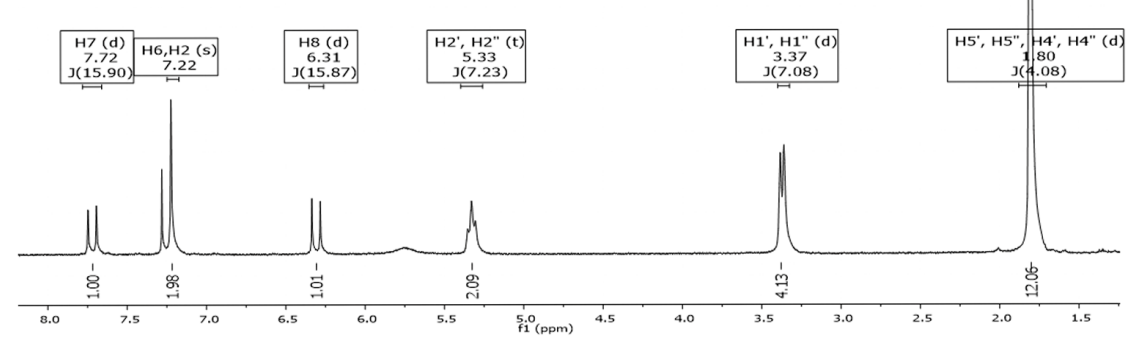

b)

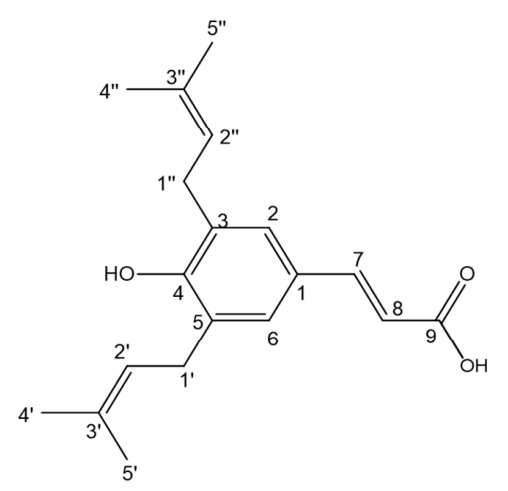

Figure 1. ArtC isolation. (a) ${ }^{1} \mathrm{H}$ NMR spectrum of ArtC (CD3OD, $300 \mathrm{MHz}$ ); (b) chemical structure of ArtC.

\subsection{ArtC Attenuates Allergic Airway Inflammation}

We and others have previously demonstrated the anti-inflammatory effect of propolis in experimental allergic asthma [8-10,27]. However, a major challenge for the development of immunotherapies employing natural products, such as propolis, is to identify the individual active compounds that display anti-inflammatory activities. In order to do that, OVA-sensitized and challenged mice were treated with ArtC (treated group) or with vehicle (PBS, non-treated group), as depicted in Figure 2a. Following treatment, mice were challenged with the allergen and lung inflammation was evaluated (Figure 2a). No 
differences in body weight were detected prior to and after treatment between treated and non-treated groups (Figure 2b).

a)

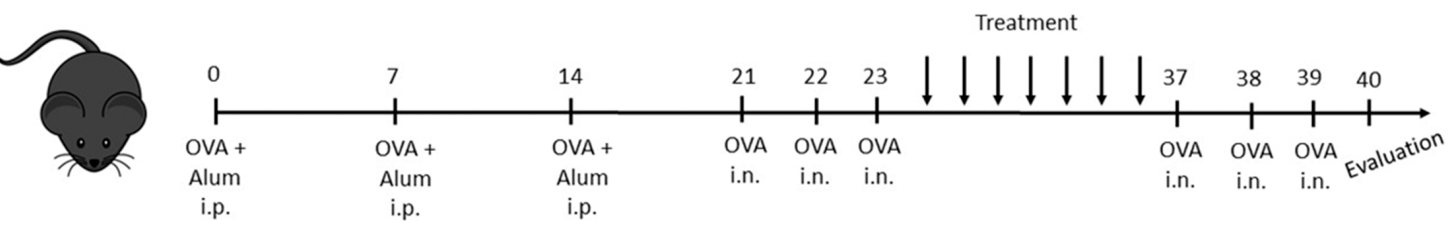

b)

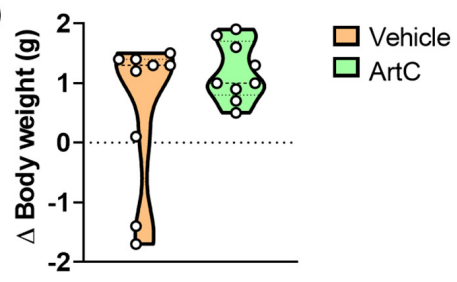

e)

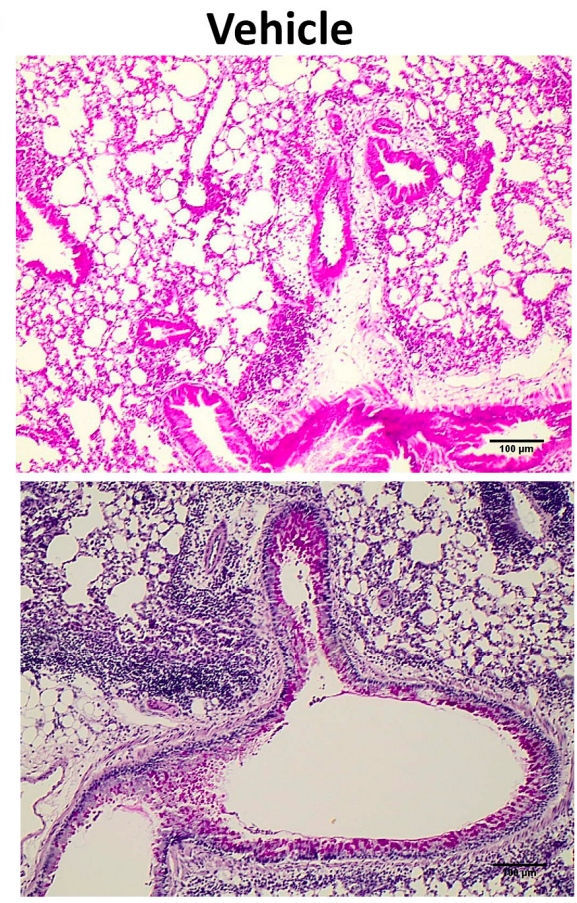

c)

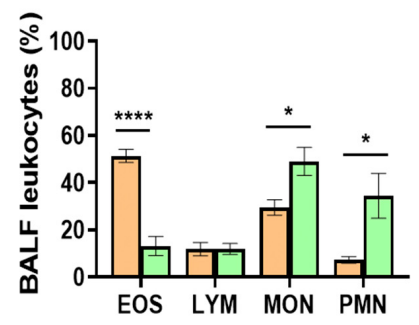

d)

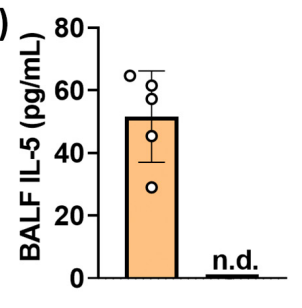

g)
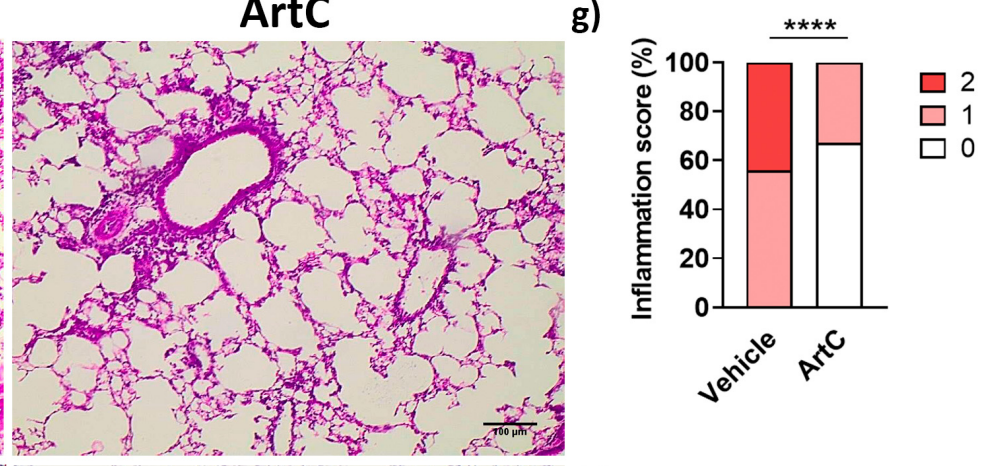

h)

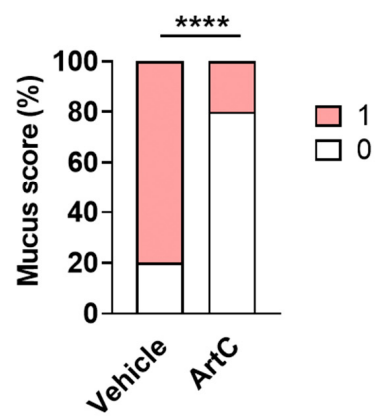

Figure 2. ArtC reduces allergic airway inflammation. (a) Experimental design; (b) body weight variation of mice exposed to the allergen before and after treatment with ArtC; (c) frequency of eosinophils (EOS), lymphocytes (LYM), mononuclear cells (MON) and polymorphonuclear cells (PMN) in the BALF; (d) IL-5 in the BALF (n.d.: not detected); (e) representative images of lung inflammation (magnification 200×, scale bar $100 \mu \mathrm{M}$ ) and (f) mucus production (magnification 200×, scale bar $100 \mu \mathrm{M})$; (g) lung inflammation score (0-without inflammation; 1 -mild; 2-moderate to severe inflammation); (h) mucus score ( 0 - without mucus secretion; 1 -mild). Data are representative of two independent experiments $\left(\mathrm{n}=4-5\right.$ /group/experiment), except for (d) (one representative experiment), and expressed by mean \pm SD. ${ }^{*} p<0.05$ and $* * * * * 0.0001$.

There was a significant reduction in the frequency of eosinophils and IL-5 levels along with an increase in mono and polymorphonuclear cells in the BALF of ArtC-treated animals compared with that of non-treated allergen-exposed mice (Figure 2c,d). No difference was found in IL-4 concentrations in lung homogenates and no IL-4 was detected in the BALF comparing groups treated or not treated with ArtC, previously exposed to OVA (vehicle group and ArtC group). IL-13 concentrations were also similar in the BALF and in the lung homogenates between both groups (data not shown). The histopathological analysis clearly showed a significant decrease in the perivascular and peribronchial cellular infiltrates 
(Figure 2e) and mucus secretion (Figure 2f) in lungs of ArtC-treated mice compared to those of animals in the vehicle-treated group. Inflammation and mucus scores were evaluated and a reduction in both parameters was observed following ArtC treatment, whereas two represented the highest level of inflammation and one the highest level of mucus production, respectively (Figure $2 \mathrm{~g}, \mathrm{~h}$ ).

Collectively, these results show that the in vivo treatment with $\mathrm{ArtC}$ reduced allergic airway inflammation in a model of OVA-induced asthma.

\subsection{ArtC Induces Treg Cells Differentiation In Vitro, but Not In Vivo}

Because we previously reported that propolis increases the differentiation of regulatory (Treg) T cells [10], we first investigated whether purified ArtC would induce Treg cells in vitro. Treg cells were differentiated from $\mathrm{CD} 4{ }^{+} \mathrm{CD} 62 \mathrm{~L}^{+}$naive $\mathrm{T}$ lymphocytes purified from spleen and lymph nodes and further cultured in the presence of recombinant IL-2 and TGF- $\beta$. Figure 3 a depicts the gate strategy used to evaluate Treg cells expressing the transcription factor Foxp3. ArtC was not toxic at concentrations up to $10 \mu \mathrm{M}$ (Figure 3b). The addition of ArtC in the latter non-toxic concentration $(10 \mu \mathrm{M})$ increased the differentiation of Treg cells compared with those cells cultured with IL-2 and TGF- $\beta$ only (CTL) (Figure 3c,d). We next evaluated the frequency of Treg cells in the lungs of ArtC-treated mice according to the gate strategy represented in Figure 3e. ArtC treatment neither affected the frequency of Foxp3 ${ }^{+}$Treg cells (Figure 3f) nor the production of IL-10 (data not shown) in the lungs of treated mice, indicating that although ArtC induced Foxp3 ${ }^{+}$Treg cells differentiation in vitro, this outcome was not observed in lungs of mice exposed to the allergen in vivo.

\subsection{ArtC Augments M-MDSC Frequency In Vitro and In Vivo}

Propolis treatment was shown to increase the differentiation of MDSC [10] and we found a significant increase in the frequencies of mononuclear and polymorphonuclear cells in the BALF of animals treated with ArtC (Figure 2c). Next, we assessed the ability of ArtC to induce the differentiation of MDSC in vitro. MDSC is a heterogeneous population of immature myeloid cells that expands in pathologic situations and exhibits suppressive functions that regulate the immune response $[19,20]$. The two subsets of MDSC, granulocytic (PMN-MDSC: Ly6G Ly6C ${ }^{\text {int }}$ ) and monocytic (M-MDSC: Ly6G- $\mathrm{Ly}^{+} \mathrm{C}^{+}$) were characterized as depicted in Figure $4 \mathrm{a}$. ArtC was not toxic at concentrations up to $20 \mu \mathrm{M}$ (Figure $4 \mathrm{~b}$ ), and therefore, for these experiments we used the same concentration of ArtC employed in Treg cell cultures $(10 \mu \mathrm{M})$ (Figure 3b). The presence of ArtC increased the frequency of M-MDSC and reduced the frequency of PMN-MDSC compared to control cells (bone marrow cells cultured with IL-6 plus GM-GSF only) (Figure 4c-e).

We also evaluated the frequency of Ly6G ${ }^{-} \mathrm{Ly} 6 \mathrm{C}^{+}$(M-MDSC) and Ly6G+ Ly6C $\mathrm{C}^{\text {int }}$ (PMNMDSC) in the lungs of mice exposed to the allergen, treated or not treated with ArtC. We used the gate strategy depicted in Figure 5a to characterize subsets of MDSC in the lungs. ArtC-treated mice exhibited an increase in the frequency (Figure $5 b, c$ ) and in the numbers (Figure 5d) of $\mathrm{Ly}_{6} \mathrm{G}^{-} \mathrm{Ly} 6 \mathrm{C}^{+}$cells but neither in the frequency (Figure 5b,e) nor in the number (Figure $5 \mathrm{f}$ ) of $\mathrm{Ly} 6 \mathrm{G}^{+} \mathrm{Ly} 6 \mathrm{C}^{\text {int }}$ cells in the lungs. We performed a correlation analysis and found a negative correlation between the frequencies of pulmonary eosinophils and Ly6G ${ }^{-} \mathrm{Ly}_{6 \mathrm{C}}^{+}$cells in vehicle-treated mice, while no significant correlation was observed in the ArtC-treated group (Figure 5g). These findings suggest that $\mathrm{Ly}_{6 \mathrm{G}}^{-} \mathrm{Ly}^{6} \mathrm{C}^{+}$cells negatively regulate eosinophilic inflammation during allergic asthma.

\subsection{M-MDSC Suppress the Allergic Airway Inflammation}

To confirm the role of M-MDSC differentiated in the presence of ArtC in downregulating allergic pulmonary inflammation, we next adoptively transferred sorted $\mathrm{M}$ MDSC generated in vitro from bone marrow in the presence or absence of ArtC. On the second day of OVA challenge, sorted M-MDSC were transferred by intrapharyngeal route 
(Figure 6a). A representative photomicrography of sorted differentiated M-MDSC before cell transfer is shown in Figure $6 \mathrm{~b}$.

a)
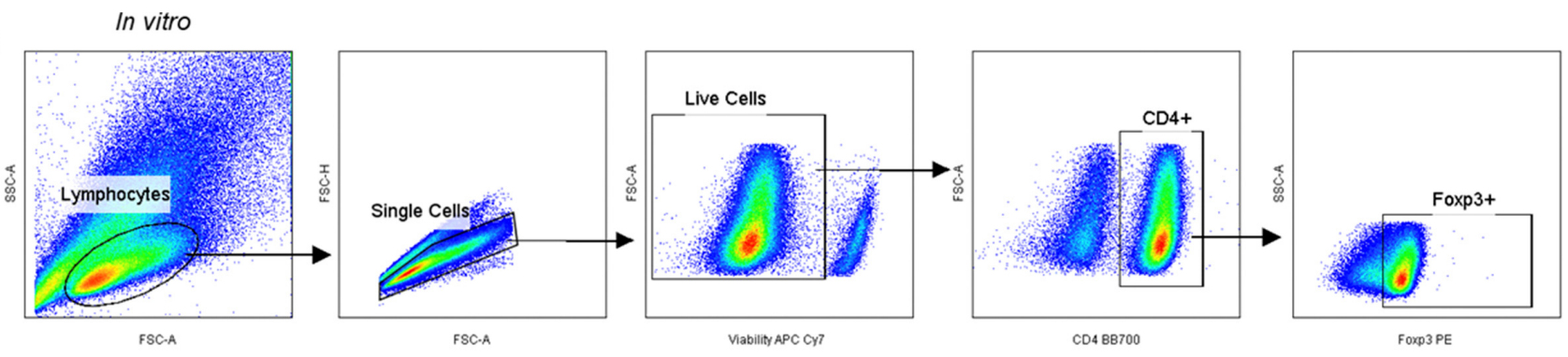

b)

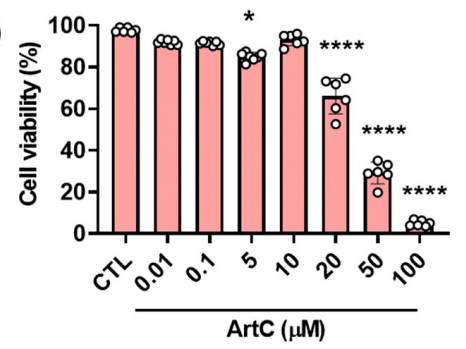

c)

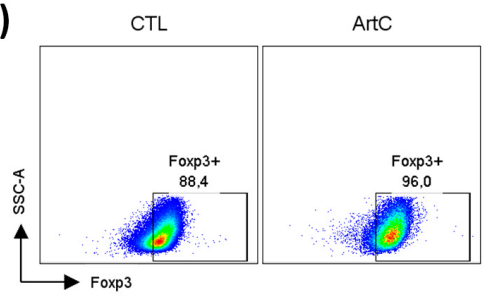

d)

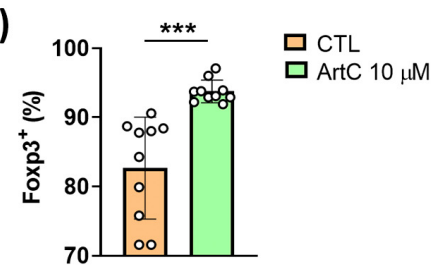

\section{e)}
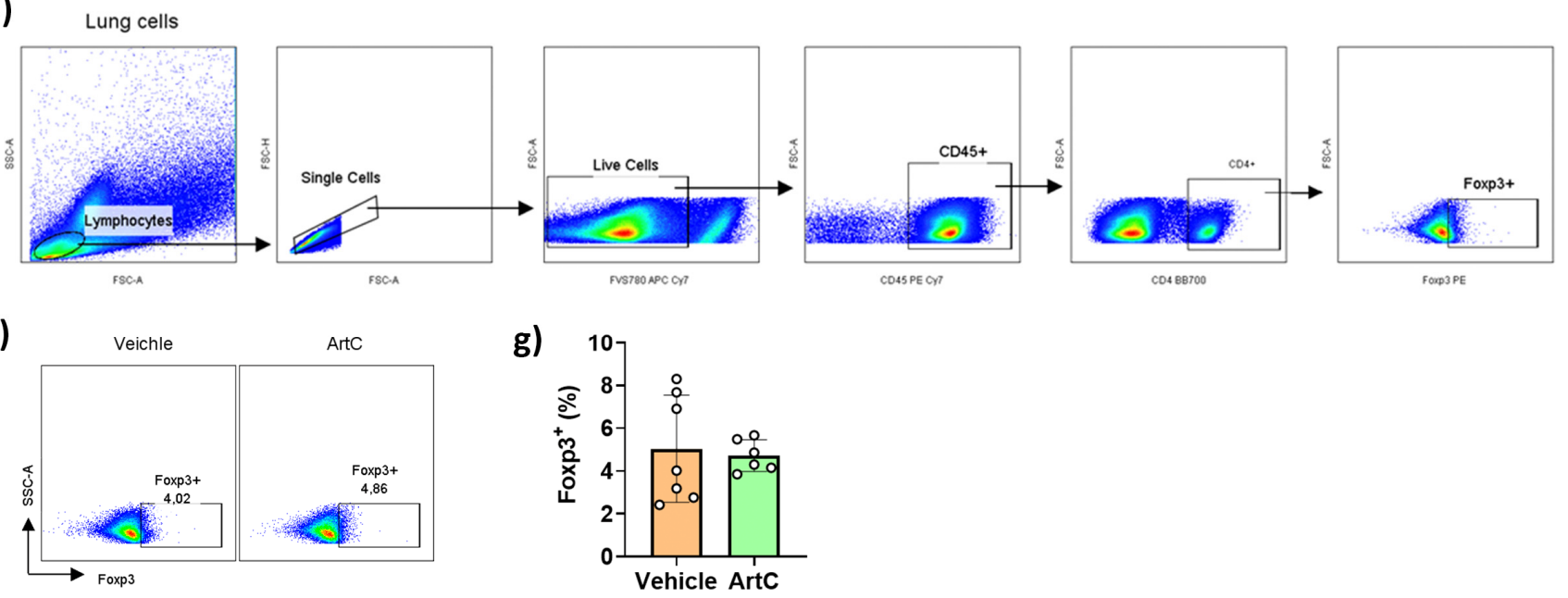

Figure 3. ArtC induces Treg cells differentiation in vitro. (a) Gate strategy for Treg cell $\left(\mathrm{CD}^{+} \mathrm{Foxp}^{+}\right)$characterization in vitro by flow cytometry; (b) frequency of live cells $\left(\mathrm{FVS} 780^{-}\right.$) in culture of $\mathrm{CD} 4^{+} \mathrm{T}$ cells stimulated with ArtC versus control (CTL); (c) representative dot plot of Treg cells generated in vitro in the presence or absence of ArtC; (d) percentage of Treg cells generated in vitro. Data are representative of three independent experiments ( $n=3-4 /$ group/experiment) and expressed by mean \pm SD; (e) gating strategy for Treg cell characterization in vivo; (f) representative dot plot of Treg cell in the lungs of mice exposed to the allergen and treated or not (vehicle) with ArtC; (g) frequency of Treg cells in the lungs. Data are representative of two independent experiments $(n=4-5$ /group/experiment) and expressed by mean \pm SD. ${ }^{*} p<0.05,{ }^{* * *} p<0.001$ and ${ }^{* * * *} p<0.0001$.

A significant reduction in both the frequency and number of eosinophils in the BALF of challenged mice was observed following ArtC-treated M-MDSC transfer (Figure 6c,d). Although a similar trend was observed following transfer of non-treated M-MDSC, the results were not significant (Figure $6 \mathrm{c}, \mathrm{d}$ ). An increase in the frequency, but not number, of monocytic cells was also observed following transfer of ArtC-treated M-MDSC (Figure $6 c, d$ ). In addition, we observed a reduction in IL-4 (Figure 6e), but not in IL-5 levels (Figure 6f) in the lungs homogenates after the transfer of ArtC-treated M-MDSC. IL-13 levels in the BALF and lungs homogenates are not changed between three groups (data not shown). Similarity, we did not observe any change in IL-10 levels in the lungs (data not shown). IL-4, IL-5 and IL-10 levels are not detected in the BALF. Flow cytome- 
try analysis showed that intrapharyngeal transfer of sorted M-MDSC increased that cell population in the lung tissue compared with the lungs of mice that did not receive cell transfer (Figure $6 \mathrm{~g}-\mathrm{i}$ ). Histological analysis revealed that transfer of both M-MDSC groups significantly decreased pulmonary infiltrates (Figure 6j) and mucus secretion (Figure 6k). However, the inflammation and mucus score (Figure $61, \mathrm{~m}$ ) were significantly lower in the lungs of mice transferred with ArtC-treated M-MDSC in comparison to those that received non-treated M-MDSC. These results confirm that ArtC treatment of M-MDSC increases their capacity in reducing eosinophil infiltration, inflammation, and mucus secretion in the lungs during airway allergic inflammation.

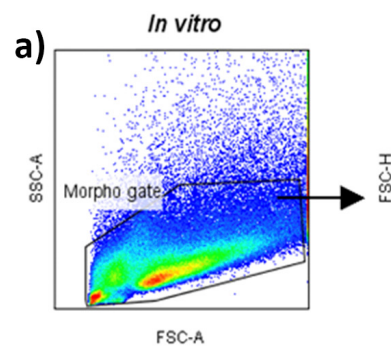

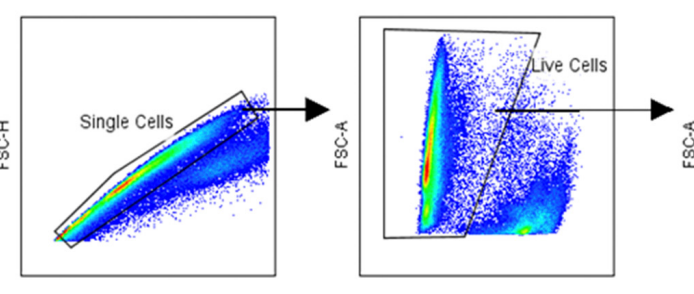

FSC.A

Viability $\mathbf{4} 50$

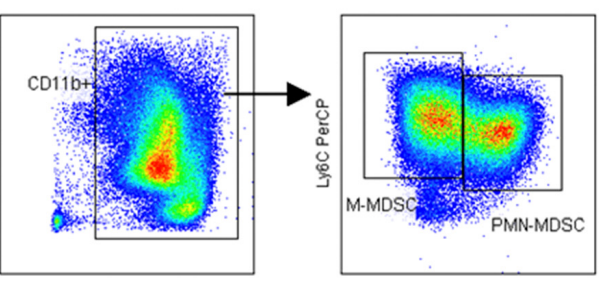

CD11b PE CY7

Ly6G FITC c)

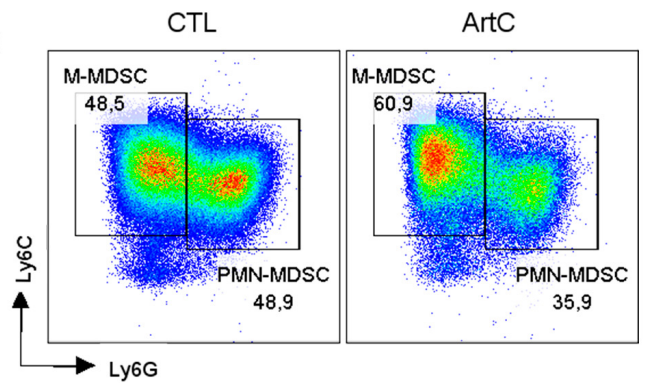

e)

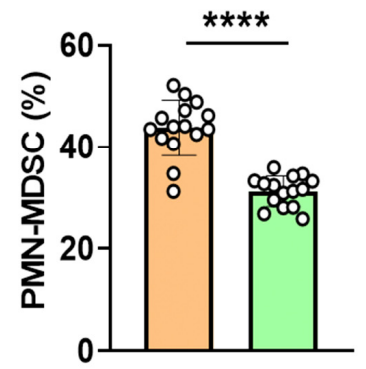

Figure 4. ArtC induces M-MDSC differentiation in vitro. (a) Gate strategy for M- (Ly6G- Ly6C ${ }^{+}$) and PMN-MDSC $\left(\right.$ Ly6G ${ }^{+}$Ly6C ${ }^{\text {int }}$ ) characterization in vitro; (b) frequency of live cells (FVS780-) in culture of bone marrow cells stimulated with rIL-6, GM-CSF and ArtC versus control (CTL); (c) representative dot plot of M- and PMN-MDSC generated in vitro in the presence of ArtC $(10 \mu \mathrm{M})$; (d) percentage of M-MDSC, and (e) PMN-MDSC. Data are representative of four independent experiments ( $\mathrm{n}=3-4$ /group/experiment) and expressed by mean \pm SD. ${ }^{*} p<0.05$ and ${ }^{* * *} p<0.0001$.

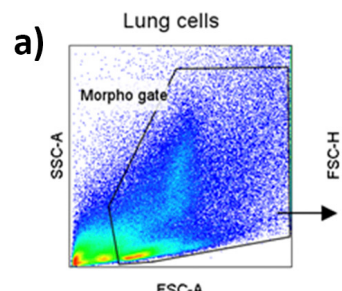

FSC-A

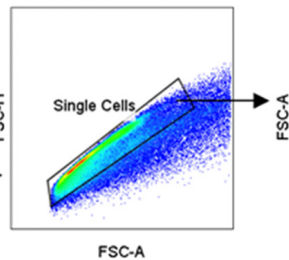

FSC.A

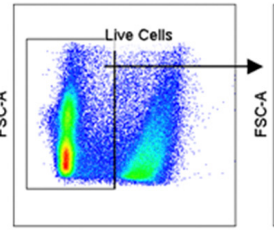

Viability APC Cy 7

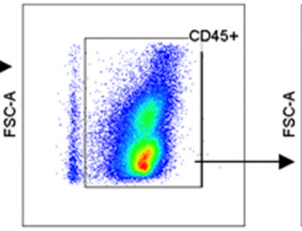

CD45 PE Cy7

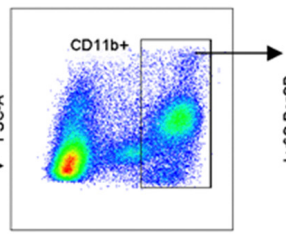

CD11b FITC

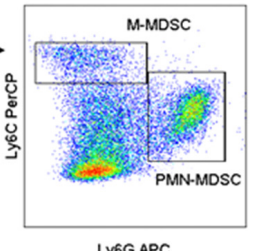

LY6G APC

Figure 5. Cont. 

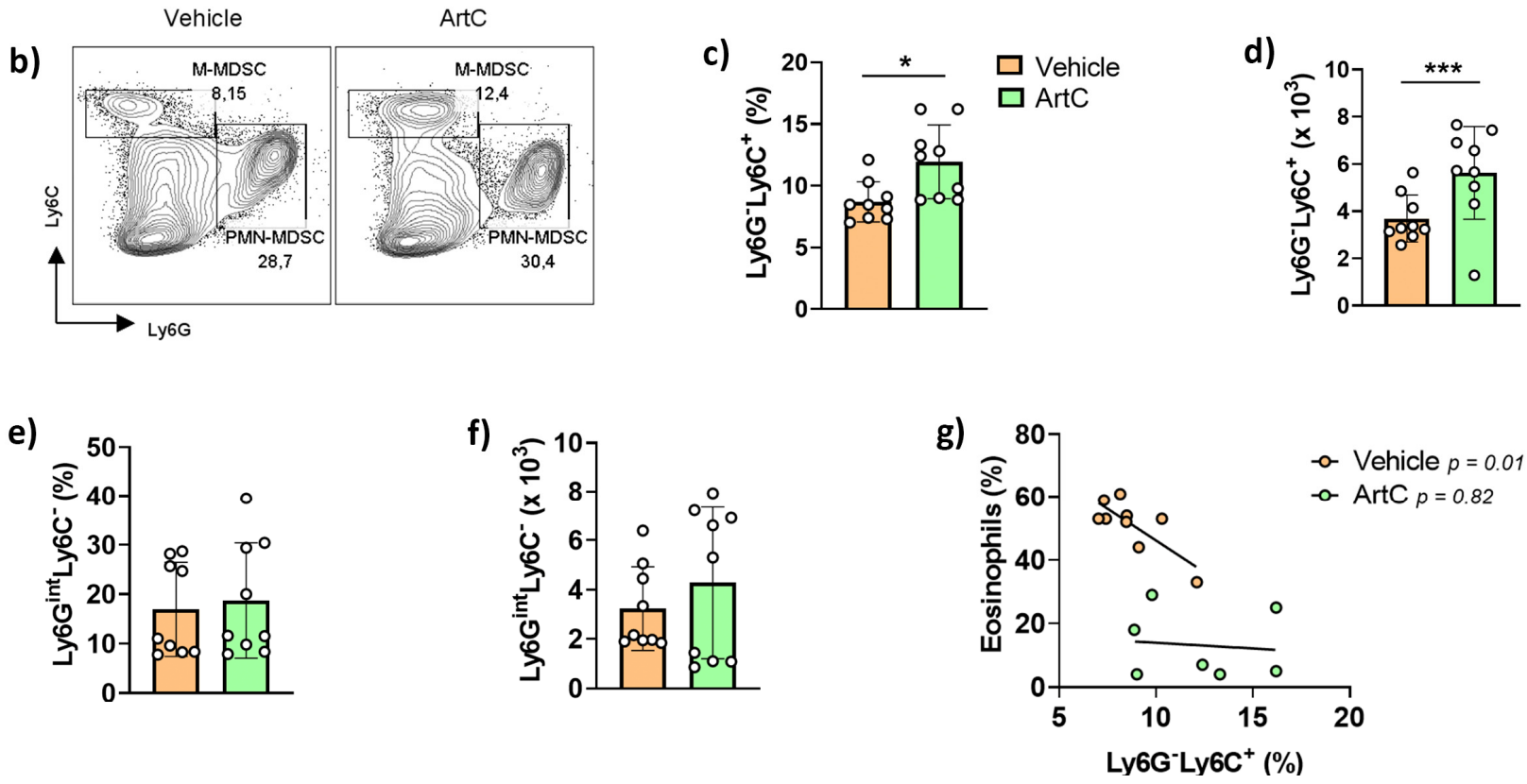

Figure 5. ArtC induces M-MDSC in the lungs of mice exposed to the allergen. (a) Gate strategy for Ly6G ${ }^{-} \mathrm{Ly}^{+} \mathrm{C}^{+}$(M-MDSC) and Ly6G ${ }^{+}$Ly6C ${ }^{\text {int }}$ (PMN-MDSC) characterization in vivo; (b) representative dot plot of $\mathrm{Ly}_{6 \mathrm{G}}{ }^{-} \mathrm{Ly}_{6 \mathrm{C}}{ }^{+}$and $\mathrm{Ly}_{6 \mathrm{G}} \mathrm{Ly}^{+} \mathrm{C}^{\text {int }}$ in the lungs of mice exposed to the allergen treated with or not (Vehicle) with ArtC; (c) frequency, and (d) absolute number of Ly6G ${ }^{-}$Ly6C $^{+}$in the lungs; (e) frequency, and (f) absolute number of Ly6G ${ }^{+}$Ly6 $\mathrm{C}^{\text {int }}$ in the lungs; (g) correlation between BALF eosinophils and lung $\mathrm{Ly}_{6 \mathrm{G}}{ }^{-} \mathrm{Ly} 6 \mathrm{C}^{+}$. Data are representative of two independent experiments $(\mathrm{n}=4-5 /$ group/experiment) and expressed by mean \pm SD. ${ }^{*} p<0.05$ and ${ }^{* * *} p<0.001$.

a)

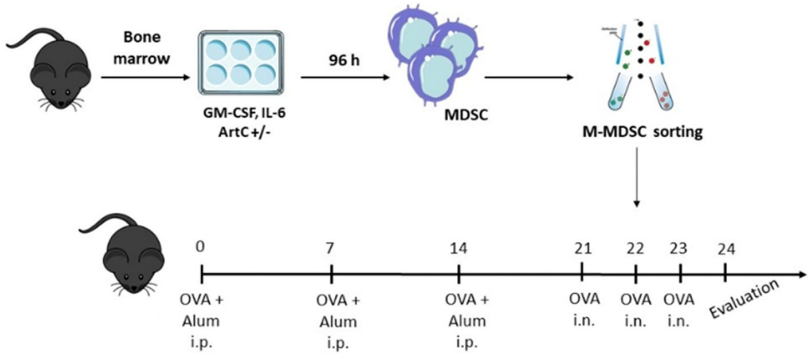

b)

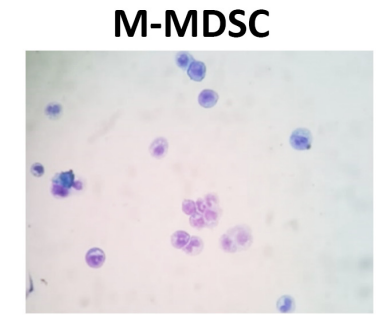

d)

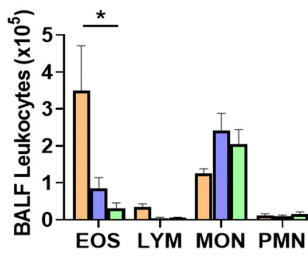

h)

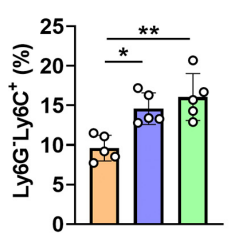

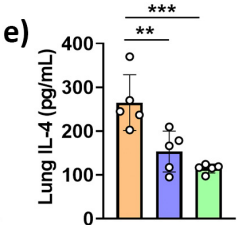

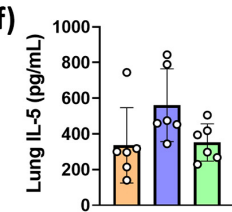

g)

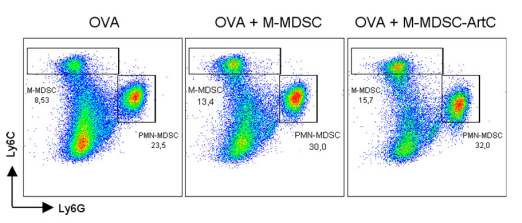

Figure 6. Cont.

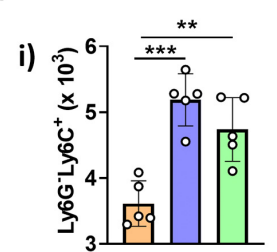


j)

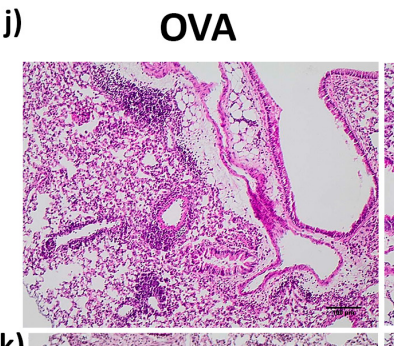

OVA + M-MDSC
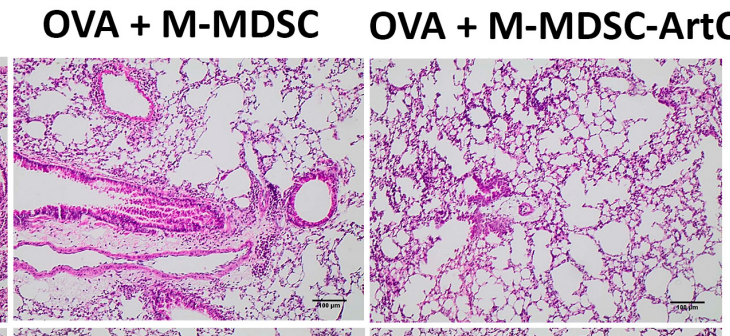

k)

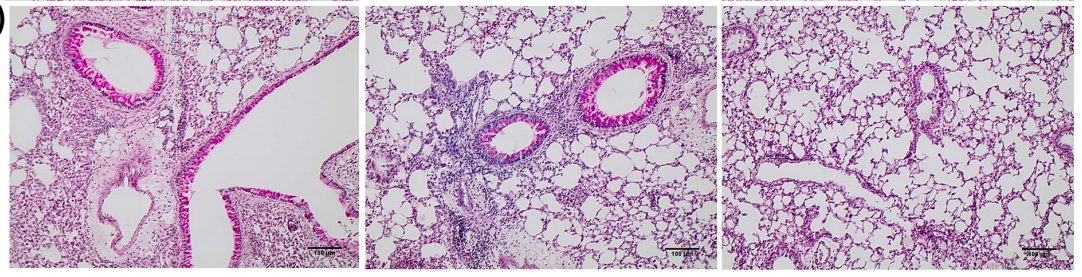

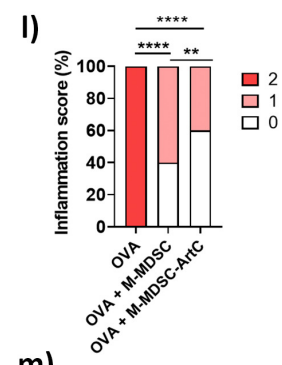

m)

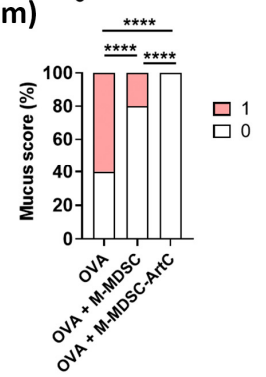

Figure 6. ArtC-induced M-MDSC reduces the allergic airway inflammation in mice. (a) Experimental design; (b) sorted M-MDSC, before cell transfer; (c) frequency and (d) number of eosinophils (EOS), lymphocytes (LYM), mononuclear cells (MON) and polymorphonuclear cells (PMN) in the BALF post cell transfer; (e) IL-4 and (f) IL-5 levels in the lungs; (g) representative dot plot of M- and PMN-MDSC in the lungs of post cell transfer; (h) percentage and (i) number of M-MDSC in the lungs; $(\mathbf{j})$ representative images of lung inflammation (magnification $200 \times$, scale bar $100 \mu \mathrm{M}$ ) and (k) mucus production (magnification $200 \times$, scale bar $100 \mu \mathrm{M}$ ); (1) Lung inflammation score (0—without inflammation; 1—mild; 2 -moderate to severe inflammation); (m) Mucus score (0-without mucus secretion; 1 -mild). Data are representative of two independent experiments ( $n=5-6$ /group/experiment), except for (e-h) (one representative experiment), and expressed by mean \pm SD. ${ }^{*} p<0.05,{ }^{* *} p<0.01,{ }^{* * *} p<0.001$ and ${ }^{* * * *} p<0.0001$.

\section{Discussion}

In this study, we show for the first time that $A r t C$, a major component of green propolis [15], induced M-MDSC in vitro differentiation and augmented the frequency of lung M-MDSC (CD11b $\left.{ }^{+} \mathrm{Ly}_{6} \mathrm{G}^{-} \mathrm{Ly} \mathrm{C}^{+}\right)$in an already established experimental model of asthma. The reduction in eosinophilic recruitment, pulmonary inflammation and mucus secretion, and the increase in M-MDSC frequency encourage the use of ArtC as a target molecule to be investigated as an adjuvant therapy for allergic asthma, which has not been previously pursued.

MDSC were primarily described in the context of tumors. Researchers observed myeloid hyperplasia in the tumor microenvironment, and later they identified that those cells displayed an immunosuppressive role [28]. Since then, the role of MDSC in tumors and other diseases has been explored. In the context of allergic asthma, MDSC can directly suppress the function of effector T (Teff) cells or induce Treg cells expansion in the lungs [29]. Cao and coworkers showed that PMN-MDSC reduced the allergic airway inflammation by inhibiting cytokine production and type 2 innate lymphoid cell (ILC2) function in a model of papain-induced lung inflammation [30]. Moreover, a previous study of our group showed that the treatment of animals exposed to allergen with green propolis induced accumulation of PMN-MDSC in lungs [10]. However, the role of M-MDSC in asthma and other allergic disorders was not known.

ArtC have been reported as an anti-inflammatory molecule [16,17,31]. Because our group previously showed that propolis treatment during experimental asthma induced Treg cells and MDSC, we considered it reasonable to investigate whether the mechanism of ArtC action would be the same as that of propolis. Although ArtC induced Treg cell differentiation in vitro, in vivo treatment with the compound failed to induce any increase in that population in the lungs of animals exposed to the allergen different from our group reported: an increase in Treg cells and PMN-MDSC in the lungs of mice exposed to the allergen and treated with propolis [10]. However, here we found an increase in M-MDSC 
in the lungs of mice treated with ArtC. These findings show that propolis and ArtC might play anti-inflammatory action through different mechanisms.

MDSC produce IL-10, TGF- $\beta$, and NO [22,32] and expresses specific markers related to their suppressive functions such as PD-L1 (Programmed Cell Death Ligand 1), iNOS (inducible Nitric Oxide Synthase), and Arg1 (Arginase 1) [23,33]. In vitro studies showed that blocking of Arg1 and iNOS increased CD8 ${ }^{+} \mathrm{T}$ and B cells proliferation [34,35], suggesting that these mediators were responsible for suppressor functions of MDSC.

In allergic asthma, Cloots and coworkers showed that mice genetically deficient for Arg1 displayed a reduction in Il4, Il5, Il13, Ccl2, and Ccl11, all Th2-related genes [36], suggesting that Arg1 may regulate type 2 inflammation. Additionally, Arg1 expression is involved in airway fibrosis and bronchial hyper-reactivity [37]. Treatment with ArtC in vitro induced the expression of Arg1 in M-MDSC (data not shown). However, animals exposed to the allergen and treated with ArtC exhibited a reduction in Arg1 expression in lung M-MDSC (data not shown). Besides the reduction in Arg1 expression, ArtC-treated mice also displayed increased expression of PD-L1, although not significant, on M-MDSC in lungs (data not shown). PD-L1 is a co-inhibitory molecule expressed by several cell types. PD-L1 binds PD-1 receptor expressed in activated T lymphocytes and induces cell death and immune suppression [38]. Thus, the PD-L1-PD-1 interaction is also a possible mechanism by which ArtC-induced M-MDSC could negatively modulate Th2 cells in allergic asthma.

Although M-MDSC transfer experiments confirmed the mechanism of action of ArtC inducing anti-inflammatory action in asthma, it remains to be investigated the exact mechanism by which M-MDSC reduces the eosinophilic influx and pulmonary inflammation in animals exposed to the allergen. These mechanisms might require Arg1, PD-L1, or other receptors or molecules that deserve further investigation.

Previous studies reported that after the adoptive transfer of MDSC to mice exposed to the allergen, those MDSC migrate to the lungs and suppress inflammation by a mechanism dependent on TGF- $\beta$ production $[39,40]$. Moreover, PMN-MDSC transfer was shown to inhibit lung inflammation, Th2-cytokine production, and ILC2 function by a mechanism dependent on COX1 expression [30]. Similarly, COX1 can be critical to PMN-MDSC expansion and function since COX1 knockout mice and aspirin-treated mice did not develop decreased lung inflammation after adoptive transfer [41]. However, to our knowledge, this is the first study that shows the anti-inflammatory potential of ArtC, a purified natural compound from propolis, in the context of allergic airway inflammation. Thus, ArtC can be selected as a target for adjuvant therapy for allergic asthma, based on its capacity to reduce eosinophilic influx, pulmonary inflammation, and mucus secretion via enhancement of M-MDSC anti-inflammatory functions.

Author Contributions: Conceptualization: N.S.M., T.F.d.C.F.S. and V.L.D.B.; formal analysis: N.S.M. and D.M.R.; funding acquisition: V.L.D.B. and J.K.B.; investigation: N.S.M., T.F.d.C.F.-S., G.F.C., M.M.M.B., L.N.Z.R., D.L.C.; methodology: N.S.M., T.F.d.C.F.-S., M.M.M.B., D.M.R., D.L.C., J.K.B. and V.L.D.B.; project administration: V.L.D.B.; resources: J.I.H., L.N.Z.R., J.K.B. and V.L.D.B.; supervision: T.F.d.C.F.-S. and V.L.D.B.; validation: N.S.M., T.F.d.C.F.-S. and V.L.D.B.; writing-original draft: N.S.M., T.F.d.C.F.S. and V.L.D.B.; writing-review and editing: D.L.C. and V.L.D.B. All authors have read and agreed to the published version of the manuscript.

Funding: This study was supported by Sao Paulo Research Foundation (FAPESP): grants 2017/216295; 2019/11213 and 2017/04138-8. N.S.M. and G.F.C. were supported by an undergraduate scholarship (FAPESP_grant numbers 2019/18793-3 and 2019/23446-0, respectively), M.M.M.B. was supported by a doctoral fellowship by the "National Council for Scientific and Technological Development (CNPq)" (CNPq - grant number 142139/2019-0), D.M.R. was supported by a doctoral fellowship by the "Coordination for the Improvement of Higher Education Personnel (CAPES)" and T.F.d.C.F.-S. was supported by a postdoctoral fellowship (FAPESP—grant number 2019/09881-6).

Institutional Review Board Statement: This study was conducted according to the guidelines of the National Council to Control Animal Experimentation (CONCEA, Brazil) and was approved by the local Committee on Ethics in the Use of Animals (protocol number 216/2019). 
Acknowledgments: The authors are thankful to Ana Flávia Gembre and Deisy Mara da Silva for technical assistance.

Conflicts of Interest: The authors declare no conflict of interest.

\section{References}

1. Bazo, A.P.; Rodrigues, M.A.M.; Sforcin, J.M.; de Camargo, J.L.V.; Ribeiro, L.R.; Salvadori, D.M.F. Protective action of propolis on the rat colon carcinogenesis. Teratog. Carcinog. Mutagen. 2002, 22, 183-194. [CrossRef] [PubMed]

2. Cornara, L.; Biagi, M.; Xiao, J.; Burlando, B. Therapeutic properties of bioactive compounds from different honeybee products. Front. Pharmacol. 2017, 8, 1-20. [CrossRef] [PubMed]

3. Orsi, R.O.; Sforcin, J.M.; Funari, S.R.C.; Bankova, V. Effects of Brazilian and Bulgarian propolis on bactericidal activity of macrophages against Salmonella Typhimurium. Int. Immunopharmacol. 2005, 5, 359-368. [CrossRef] [PubMed]

4. Sforcin, J.M. Propolis and the immune system: A review. J. Ethnopharmacol. 2007, 113, 1-14. [CrossRef] [PubMed]

5. Machado, J.L.; Assunção, A.K.M.; Da Silva, M.C.P.; Dos Reis, A.S.; Costa, G.C.; Arruda, D.D.S.; Rocha, B.A.; Vaz, M.M.; Paes, A.M.; Guerra, R.N.M.; et al. Brazilian green propolis: Anti-inflammatory property by an immunomodulatory activity. Evid.-Based Complement. Altern. Med. 2012, 2012, 157652. [CrossRef] [PubMed]

6. Al-Hariri, M.T.; Eldin, T.G.; Hashim, T.; Chathoth, S.; Alswied, A. Propolis Modulates Inflammatory Mediators and Improves Histopathology in Male Rats with L-arginine-induced Acute Pancreatitis. Sultan Qaboos Univ. Med. J. 2019, 19, 103. [CrossRef] [PubMed]

7. Costa, P.; Somensi, L.B.; da Silva, R.d.C.M.V.d.A.; Mariano, L.N.B.; Boeing, T.; Longo, B.; Perfoll, E.; de Souza, P.; Gushiken, L.F.S.; Pellizzon, C.H.; et al. Role of the antioxidant properties in the gastroprotective and gastric healing activity promoted by Brazilian green propolis and the healing efficacy of Artepillin C. Inflammopharmacology 2020, 28, 1009-1025. [CrossRef] [PubMed]

8. Sy, L.B.; Wu, Y.L.; Chiang, B.L.; Wang, Y.H.; Wu, W.M. Propolis extracts exhibit an immunoregulatory activity in an OVA-sensitized airway inflammatory animal model. Int. Immunopharmacol. 2006, 6, 1053-1060. [CrossRef] [PubMed]

9. De Farias, J.H.C.D.; Reis, A.S.; Araújo, M.A.R.; Araújo, M.J.A.M.; Assunção, A.K.M.; De Farias, J.C.; Fialho, E.M.S.; Silva, L.A.; Costa, G.C.; Guerra, R.N.M.; et al. Effects of stingless bee propolis on experimental asthma. Evid.-Based Complement. Altern. Med. 2014, 2014. [CrossRef] [PubMed]

10. Piñeros, A.R.; de Lima, M.H.F.; Rodrigues, T.; Gembre, A.F.; Bertolini, T.B.; Fonseca, M.D.; Berretta, A.A.; Ramalho, L.N.Z.; Cunha, F.Q.; Hori, J.I.; et al. Green propolis increases myeloid suppressor cells and CD4+Foxp3+ cells and reduces Th2 inflammation in the lungs after allergen exposure. J. Ethnopharmacol. 2020, 252, 112496. [CrossRef] [PubMed]

11. Global Asthma Network. The Global Asthma Report 2018; Global Asthma Network: Auckland, New Zeland, 2018; ISBN 9780473465230.

12. Lambrecht, B.N.; Hammad, H. The immunology of asthma. Nat. Immunol. 2015, 16, 45-56. [CrossRef] [PubMed]

13. Russell, R.J.; Brightling, C.E. Pathogenesis of asthma: Implications for precision medicine. Clin. Sci. 2017, 131, 1723-1735. [CrossRef] [PubMed]

14. De Leonibus, C.; Attanasi, M.; Roze, Z.; Martin, B.; Marcovecchio, M.L.; Di Pillo, S.; Chiarelli, F.; Mohn, A. Influence of inhaled corticosteroids on pubertal growth and final height in asthmatic children. Pediatr. Allergy Immunol. 2016, 27, 499-506. [CrossRef] [PubMed]

15. Beserra, F.P.; Gushiken, L.F.S.; Hussni, M.F.; Ribeiro, V.P.; Bonamin, F.; Jackson, C.J.; Pellizzon, C.H.; Bastos, J.K. Artepillin C as an outstanding phenolic compound of Brazilian green propolis for disease treatment: A review on pharmacological aspects. Phytother. Res. 2021, 35, 2274-2286. [CrossRef] [PubMed]

16. Szliszka, E.; Mertas, A.; Czuba, Z.P.; Król, W. Inhibition of inflammatory response by artepillin c in activated raw264.7 macrophages. Evid.-Based Complement. Altern. Med. 2013, 2013, 735176. [CrossRef] [PubMed]

17. Paulino, N.; Abreu, S.R.L.; Uto, Y.; Koyama, D.; Nagasawa, H.; Hori, H.; Dirsch, V.M.; Vollmar, A.M.; Scremin, A.; Bretz, W.A. Anti-inflammatory effects of a bioavailable compound, Artepillin C, in Brazilian propolis. Eur. J. Pharmacol. 2008, 587, 296-301. [CrossRef] [PubMed]

18. Zhao, S.T.; Wang, C.Z. Regulatory T cells and asthma. J. Zhejiang Univ. Sci. B 2018, 19, 663-673. [CrossRef] [PubMed]

19. Nagaraj, S.; Youn, J.-I.; Gabrilovich, D.I. Reciprocal Relationship between Myeloid-Derived Suppressor Cells and T Cells. J. Immunol. 2013, 191, 17-23. [CrossRef] [PubMed]

20. Consonni, F.M.; Porta, C.; Marino, A.; Pandolfo, C.; Mola, S.; Bleve, A.; Sica, A. Myeloid-derived suppressor cells: Ductile targets in disease. Front. Immunol. 2019, 10, 1-15. [CrossRef] [PubMed]

21. Gantt, S.; Gervassi, A.; Jaspan, H.; Horton, H. The role of myeloid-derived suppressor cells in immune ontogeny. Front. Immunol. 2014, 5, 1-6. [CrossRef] [PubMed]

22. Gabrilovich, D.I. Myeloid-derived suppressor cells. Cancer Immunol. Res. 2017, 5, 3-8. [CrossRef] [PubMed]

23. Veglia, F.; Sanseviero, E.; Gabrilovich, D.I. Myeloid-derived suppressor cells in the era of increasing myeloid cell diversity. Nat. Rev. Immunol. 2021, 21, 485-498. [CrossRef] [PubMed]

24. Rodrigues, D.M.; De Souza, M.C.; Arruda, C.; Pereira, R.A.S.; Bastos, J.K. The Role of Baccharis dracunculifolia and its Chemical Profile on Green Propolis Production by Apis mellifera. J. Chem. Ecol. 2020, 46, 150-162. [CrossRef] [PubMed] 
25. Prado, R.Q.; Bertolini, T.B.; Piñeros, A.R.; Gembre, A.F.; Ramos, S.G.; Silva, C.L.; Borges, M.C.; Bonato, V.L.D. Attenuation of experimental asthma by mycobacterial protein combined with CpG requires a TLR9-dependent IFN- $\gamma$-CCR2 signalling circuit. Clin. Exp. Allergy 2015, 45, 1459-1471. [CrossRef] [PubMed]

26. Solito, S.; Pinton, L.; De Sanctis, F.; Ugel, S.; Bronte, V.; Mandruzzato, S.; Marigo, I. Methods to Measure MDSC Immune Suppressive Activity In Vitro and In Vivo. Curr. Protoc. Immunol. 2019, 124, e61. [CrossRef] [PubMed]

27. El-Aidy, W.K.; Ebeid, A.A.; Sallam, A.E.R.M.; Muhammad, I.E.; Abbas, A.T.; Kamal, M.A.; Sohrab, S.S. Evaluation of propolis, honey, and royal jelly in amelioration of peripheral blood leukocytes and lung inflammation in mouse conalbumin-induced asthma model. Saudi J. Biol. Sci. 2015, 22, 780-788. [CrossRef] [PubMed]

28. Talmadge, J.E.; Gabrilovich, D.I. History of myeloid-derived suppressor cells. Nat. Rev. Cancer 2013, 13, 739-752. [CrossRef] [PubMed]

29. Kolahian, S.; Öz, H.H.; Zhou, B.; Griessinger, C.M.; Rieber, N.; Hartl, D. The emerging role of myeloid-derived suppressor cells in lung diseases. Eur. Respir. J. 2016, 47, 967-977. [CrossRef] [PubMed]

30. Cao, Y.; He, Y.; Wang, X.; Liu, Y.; Shi, K.; Zheng, Z.; Su, X.; Lei, A.; He, J.; Zhou, J. Polymorphonuclear myeloid-derived suppressor cells attenuate allergic airway inflammation by negatively regulating group 2 innate lymphoid cells. Immunology 2019, 156, 402-412. [CrossRef] [PubMed]

31. Ikeda, R.; Yanagisawa, M.; Takahashi, N.; Kawada, T.; Kumazawa, S.; Yamaotsu, N.; Nakagome, I.; Hirono, S.; Tsuda, T. Brazilian propolis-derived components inhibit TNF- $\alpha$-mediated downregulation of adiponectin expression via different mechanisms in 3T3-L1 adipocytes. Biochim. Biophys. Acta Gen. Subj. 2011, 1810, 695-703. [CrossRef] [PubMed]

32. Ray, P.; Arora, M.; Poe, S.L.; Ray, A. Lung myeloid-derived suppressor cells and regulation of inflammation. Immunol. Res. 2011, 50, 153-158. [CrossRef] [PubMed]

33. Wu, C.; Tan, X.; Hu, X.; Zhou, M.; Yan, J.; Ding, C. Tumor Microenvironment following Gemcitabine Treatment Favors Differentiation of Immunosuppressive Ly6C high Myeloid Cells. J. Immunol. 2020, 204, 212-223. [CrossRef] [PubMed]

34. Drabczyk-Pluta, M.; Werner, T.; Hoffmann, D.; Leng, Q.; Chen, L.; Dittmer, U.; Zelinskyy, G. Granulocytic myeloid-derived suppressor cells suppress virus-specific CD8+ T cell responses during acute Friend retrovirus infection. Retrovirology 2017, 14, 1-14. [CrossRef] [PubMed]

35. Jaufmann, J.; Lelis, F.J.N.; Teschner, A.C.; Fromm, K.; Rieber, N.; Hartl, D.; Beer-Hammer, S. Human monocytic myeloid-derived suppressor cells impair B-cell phenotype and function in vitro. Eur. J. Immunol. 2020, 50, 33-47. [CrossRef] [PubMed]

36. Cloots, R.H.E.; Sankaranarayanan, S.; Poynter, M.E.; Terwindt, E.; van Dijk, P.; Lamers, W.H.; Eleonore Köhler, S. Arginase 1 deletion in myeloid cells affects the inflammatory response in allergic asthma, but not lung mechanics, in female mice. BMC Pulm. Med. 2017, 17, 1-15. [CrossRef] [PubMed]

37. Barron, L.; Smith, A.M.; El Kasmi, K.C.; Qualls, J.E.; Huang, X.; Cheever, A.; Borthwick, L.A.; Wilson, M.S.; Murray, P.J.; Wynn, T.A. Role of Arginase 1 from Myeloid Cells in Th2-Dominated Lung Inflammation. PLoS ONE 2013, 8, e61961. [CrossRef] [PubMed]

38. Sun, C.; Mezzadra, R.; Schumacher, T.N. Regulation and Function of the PD-L1 Checkpoint. Immunity 2018, 48, 434-452. [CrossRef] [PubMed]

39. Fan, H.Z.; Yu, H.P.; Yu, R.; Zhang, Y.; Deng, H.J.; Chen, X. Passive transfer of lipopolysaccharide-derived myeloid-derived suppressor cells inhibits asthma-related airway inflammation. Eur. Rev. Med. Pharmacol. Sci. 2015, 19, 4171-4181. [PubMed]

40. Song, C.; Yuan, Y.; Wang, X.M.; Li, D.; Zhang, G.M.; Huang, B.; Feng, Z.H. Passive transfer of tumour-derived MDSCs inhibits asthma-related airway inflammation. Scand. J. Immunol. 2014, 79, 98-104. [CrossRef] [PubMed]

41. Shi, M.; Shi, G.; Tang, J.; Kong, D.; Bao, Y.; Xiao, B.; Zuo, C.; Wang, T.; Wang, Q.; Shen, Y.; et al. Myeloid-derived suppressor cell function is diminished in aspirin-triggered allergic airway hyperresponsiveness in mice. J. Allergy Clin. Immunol. 2014, 134, 1163-1174.e16. [CrossRef] [PubMed] 